Balancing the needs of capercaillie (Tetrao urogallus) and moose (Alces alces) in large-scale human land use

\title{
Sirkiä, Saija
}

2010

Sirkiä , S , Pellikka , J \& Lindén , H 2010 , ' Balancing the needs of capercaillie (Tetrao urogallus) and moose (Alces alces) in large-scale human land use ' , European Journal of Wildlife Research, vol. 56 , no. 3 , pp. 249-260 . https://doi.org/10.1007/s10344-009-0306-z

http://hdl.handle.net/10138/24166

https://doi.org/10.1007/s10344-009-0306-z

acceptedVersion

Downloaded from Helda, University of Helsinki institutional repository.

This is an electronic reprint of the original article.

This reprint may differ from the original in pagination and typographic detail.

Please cite the original version. 
4 Balancing the needs of capercaillie (Tetrao urogallus)

\begin{abstract}
The capercaillie has been negatively affected by the loss of mature forests. However, forestry creates young plantations offering a superabundant food supply for moose. Using two spatial scales, we tested whether the landscape-level environmental requirements of the capercaillie and moose differ. We compared the spatial association between the abundances of the two species in 50-x $50-\mathrm{km}$ grids and, using a set of regression models, analyzed how it was affected by various land use variables in five regions of Finland. Both species were generally most abundant in the same grid cells. Moreover, the association between abundance and several landscape variables was very similar for both species. Forest cover had a positive impact on both species in Eastern and South-Western Finland. Only in Western Finland was the capercaillie more positively associated with older forest than the moose. Human impact variables were negatively related to both capercaillie and moose abundance in Eastern and SouthWestern Finland, the effect being stronger for capercaillie. In Northern Finland, human impact turned positive. Our results highlight that, on broad landscape and regional
\end{abstract}

Communicated by W. Lutz

S. Sirkiä $(\bowtie)$

Department of Biological and Environmental Sciences,

University of Helsinki,

P.O. Box 65, Helsinki FI-00014, Finland

e-mail: saija.sirkia@helsinki.fi

S. Sirkiä $\cdot$ J. Pellikka $\cdot$ H. Lindén

Finnish Game and Fisheries Research Institute,

P.O. Box 2, FI-00791 Helsinki, Finland

J. Pellikka

Department of Sociology and Social Policy,

University of Joensuu,

P.O. Box 111, FI-80101 Joensuu, Finland scales, we might not need to make trade-offs in management decisions concerning capercaillie and moose. While considering regional land use planning, the primary goal for both species seems to be to secure large areas of forest, preferably at a distance from human settlement.

Keywords Forestry - Game management .

Landscape ecology $\cdot$ Macroecology $\cdot$ Wildlife triangle

\section{Introduction}

The capercaillie (Tetrao urogallus) and moose (Alces alces) are fundamentally important elements of the northern boreal forest fauna. The capercaillie is generally considered as a species of the wilderness, avoiding humans (e.g., Helle et al. 1994; Storch 2000b), while the moose exploits cultivations and forest plantations in an opportunistic manner (Haagenrud et al. 1987; however, see Nikula et al. 2004). The importance of young forest classes for moose (Cederlund and Okarma 1988) seems to be in contrast to the preference of mature stands by capercaillie (e.g., Seiskari 1958; Angelstam 2004). Both species have a long history of coexistence with people, as a desired target for hunters and also regarding social, cultural, and spiritual values (e.g., Taavitsainen 1980; Storch 2000a). However, their contrasting population development has created a situation where the moose, although still the most valuable species for hunters, is often regarded as a pest among the general public due to increased traffic collisions and damage to forestry and agriculture (Child and Stuart 1987; Haagenrud et al. 1987; Lavsund 1987), whereas the capercaillie is considered as a focal symbol of healthy forests with potential umbrella species characteristics (Lindén 2002a; Suter et al. 2002; Pakkala et al. 2003). 
In Finland, the winter populations of moose have increased from some hundred individuals in the 1920s to approximately 100,000 individuals in 1980, the most recent estimate being 86,000 individuals (Fig. 1; Nygrén 1987, 1996; Pusenius et al. 2008). The enormous increase in pine plantations, well-designed selective harvesting, and very small populations of large carnivores have been thought to be responsible for the increase (e.g., Nygrén 1987; Cederlund and Okarma 1988). In contrast, the abundant capercaillie populations in the first half of the twentieth century have seriously declined, and in Finland, only 20 $60 \%$ of the earlier populations are left, depending on the region (Fig. 1; Lindén 2002b). This decrease is usually associated with the effects of forestry and other human land use, leading to habitat loss, forest fragmentation, and habitat deterioration (e.g., Bevanger 1995; Baines and Summers 1997; Storch 2000b; Ludwig et al. 2008).

Habitat suitability models created for both capercaillie and moose suggest that habitat variables may differ in importance according to the spatial scale (Dussault et al. 2005; Graf et al. 2005). Thus, analyses on many spatial scales are required to build a realistic model (e.g., Wiens 1989; Levin 1992). Habitat suitability models for moose combine information on food availability and cover, thus stressing the importance of deciduous trees and young pine plantations at the forest stand and home-range scales but mature ( $\geq 30$ years old) coniferous forests at the landscape level (e.g., Allen et al. 1988; Heikkilä and Härkönen 1993; Dussault et al. 2005, 2006). For capercaillie, the total proportion of forest and bilberry cover have been found to be the most important predictors of species occurrence at home-range and landscape levels (Storch 1993a; Helle et al. 1994; Graf et al. 2005, 2007; Miettinen et al. 2008), but mature ( $>50$ years old) successional stages are usually preferred at the forest stand scale, especially by older males (e.g., Gjerde and Wegge 1989; Storch 1993b). However, young thinning forests (typically 30-55 years old) have more recently been found to be positively associated with

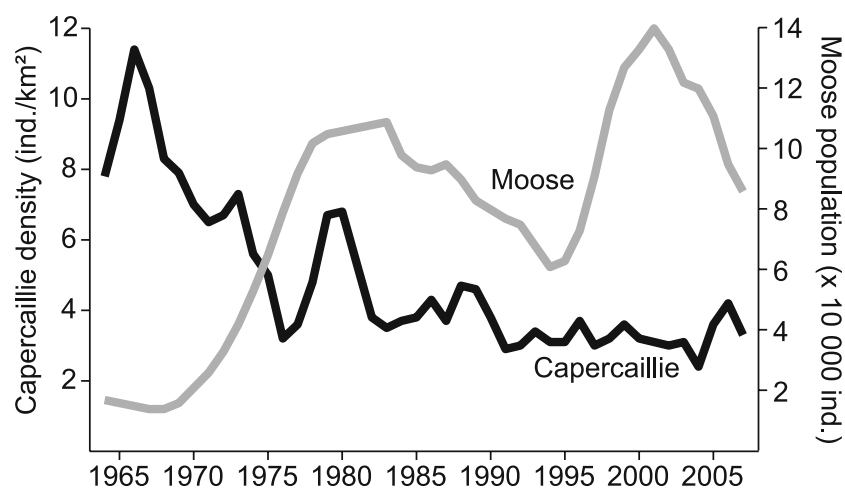

Fig. 1 The abundance estimates of capercaillie and moose, attained from wildlife triangle data, from 1964 to 2008 capercaillie density throughout Finland (Miettinen et al. 2008), and capercaillie males have formed new lekking sites in young (26-46 years old) forests both in Norway and in Finland (Rolstad et al. 2007; Valkeajärvi et al. 2007).

When broadening the scope from habitat and landscape levels (i.e., a mosaic of habitats, sensu Forman and Godron 1986) to a large-scale environment (i.e., mosaic of landscapes), different biological variables may become important. Macroecology aims to reveal the general mechanisms behind broadly occurring patterns and processes on organism, population, and ecosystem levels (Smith et al. 2008). From a species conservation perspective, it is especially important to examine the contribution of human activities to these patterns (Gaston 2004), such as how human influence is shaping the abundance and distribution of species and species richness (Pautasso 2007; Smith et al. 2008). In many cases, macroecological studies can provide tools for better informed land use planning and management decisions, not only considering spatial scale information (e.g., Whittingham et al. 2007; Fortin et al. 2008) but also temporal scales (e.g., Webb et al. 2007).

The suggested polarity in the habitat use of capercaillie and moose has led us to test whether these two species also differ in their responses towards large-scale human land use and forestry activities. In other words, we have sought to determine whether trade-offs are necessary in decisions concerning large-scale land use planning and the management of these two species (trade-off hypothesis). In this paper, we assess whether (and how) differences between the responses of the species exist on two spatial scales: in 50- $\times$ $50-\mathrm{km}$ grids and in five regions that cover the whole of Finland.

\section{Materials and methods}

Species abundance data and spatial scales

The abundance of capercaillie and moose (Table 1) was examined using data from the wildlife triangle scheme (see Lindén et al. 1996). The wildlife triangle network consists of 1,650 triangles, from which 800-900 are counted twice a year, in winter (January-March) and in late summer, (August) mainly by volunteer hunters. The network covers Finland in a regionally representative way. These census routes are equilateral triangles with $4-\mathrm{km}$ sides, thus forming a route of $12 \mathrm{~km}$. Moose abundance is estimated in winter by counting snow tracks crossing the census line (tracks/10 km/day), whereas capercaillie abundance is based on grouse counts during August, using the same triangles (individuals per square kilometer of forest land). All grouse species are counted in a 60-m-wide census belt using a three-person chain (Rajala 1974). 


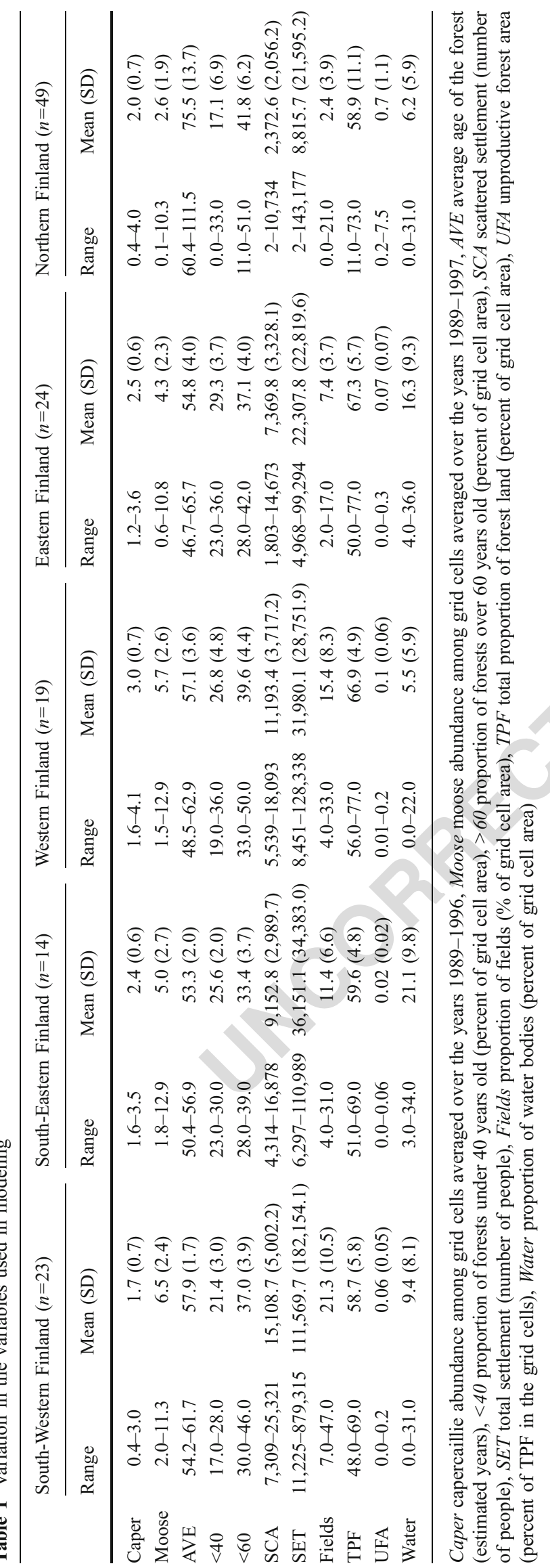

We pooled the data from individual triangles and calculated the species abundances for $50-\times 50-\mathrm{km}$ grid cells $(n=131)$ that cover the whole of Finland (Fig. 2). The grid cell system was selected as the first spatial scale for several reasons. First and foremost, we were interested in the effects of land use patterns on large-scale differences in the abundances of capercaillie and moose, and we assumed that the patterns behind these differences indeed operate at relatively broad spatial scales (e.g., Kie et al. 2002; Mikusiñski and Angelstam 2004; Miettinen et al. 2008) and rely mostly on population-level processes, such as birth, death, immigration, and emigration (e.g., Andrewartha and Birch 1954). Our approach was not to concentrate on

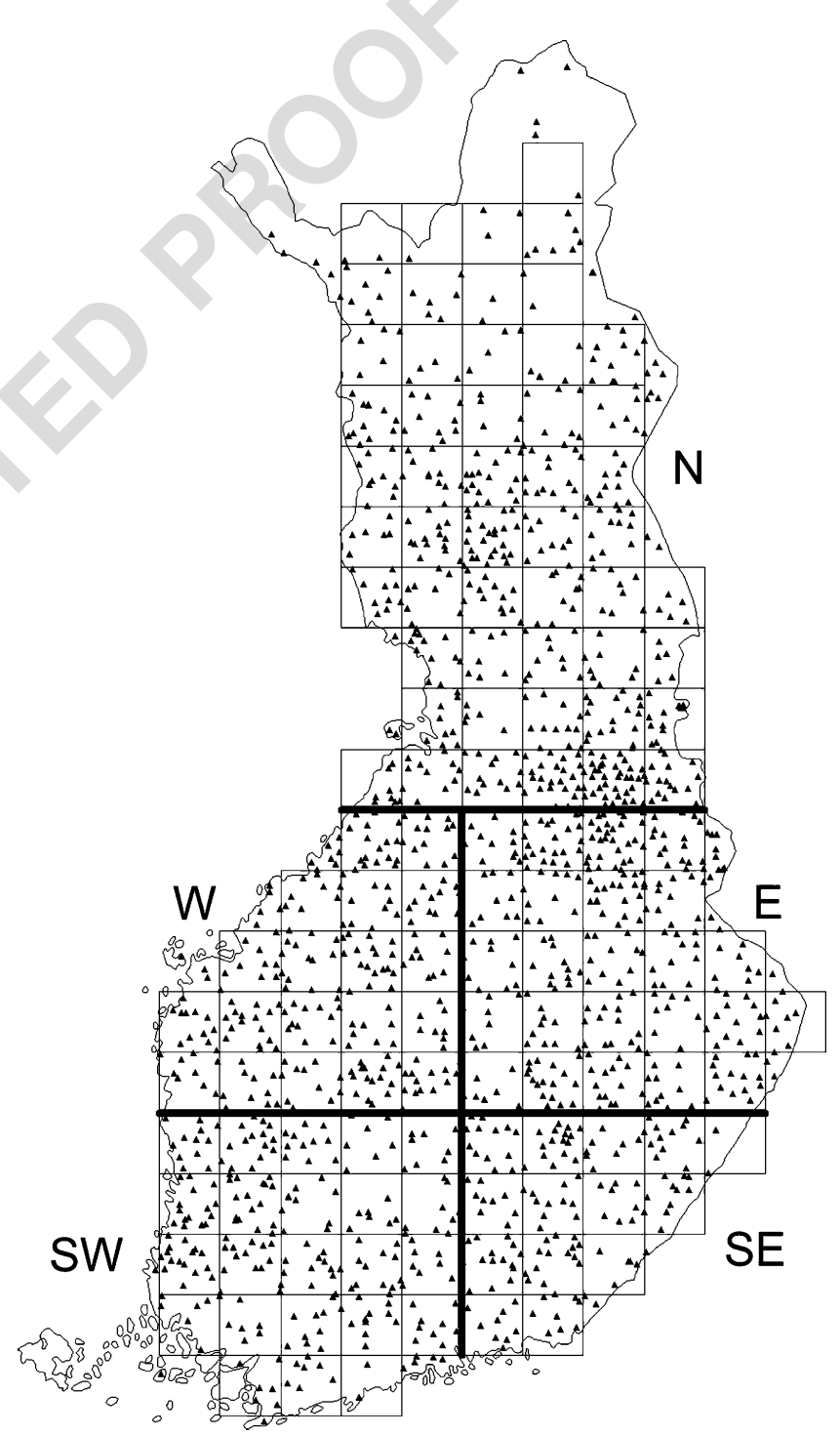

Fig. 2 The wildlife triangle network in Finland, including the grid cell $(50 \times 50 \mathrm{~km})$ system used in the analyses and the five regions: SouthWestern $(S W ; n=23)$, South-Eastern $(S E ; n=14)$, Western $(W ; n=19)$, Eastern $(E ; n=24)$ and Northern $(N ; n=51)$ Finland. Two grid cells in Northern Finland were excluded from the statistical analyses (total $n=$ 129) and one from correlation calculations (total $n=130$ ) 
individual habitat selection, although some of the large-scale phenomena we describe may be a result of processes operating at smaller scales (e.g., individual or local landscape scale; Johnson 1980).

Second, we needed a scale that could offer a representative sample of observations (here, wildlife triangles). During the study period (1989-1996), there were on average 51 wildlife triangle counts (range, 3-210, $\mathrm{SD}=$ 28.8 ) in every grid cell; thus, more than $600 \mathrm{~km}$ per grid cell was covered during that time, and almost 79,000 km nationwide. The abundances within the grid cells are therefore likely to be representative. Moreover, seasonal movements of moose extend over areas within a maximum radius of about $30-40 \mathrm{~km}$ in Finland (Heikkinen 2000).

Finally, we aimed to incorporate the assumed regional differences in Finland regarding the moose-capercaillie trade-off in linear regression models. Thus, as the second spatial scale, we selected five study regions in Finland (Fig. 2; see details in "Statistical analyses"). South-Western Finland is under the heaviest human impact, with large areas being reserved for cultivated fields (mean $=21 \%$ of the grid cell area) and human settlement. In the eastern areas (Eastern and South-Eastern Finland), the area under cultivation is the smallest (7-11\%) compared to other parts of the country, whereas the total area of water bodies is dramatically larger in the east compared to the west (Table 1). Northern Finland is probably the most distinctive region, with the lowest overall productivity, the oldest average age of the forest, and the lowest degree of human impact (see Table 1).

\section{Land use data}

The land use data were compiled from multiple sources. Forest variables were derived from the Finnish Forest Research Institute's 8th National Forest Survey 1986-1994 (Tomppo et al. 1998). The proportions of predominant tree species and the age and development classes were calculated for each municipality and subsequently as averages for each $5-0 \times 50-\mathrm{km}$ grid cell using the relative proportions of the municipalities as weights. The total proportion of forest land (TPF) included all the forest with an average growth of $\geq 1 \mathrm{~m}^{3} \mathrm{ha}^{-1}$ year $^{-1}$ (Table 1). Unproductive forest area included idle land and other forest areas with an average growth $<1 \mathrm{~m}^{3} \mathrm{ha}^{-1}$ year $^{-1}$ and was calculated as a proportion of TPF. The proportions of forest under 40 years and over 60 years, as well as the average age of forest, were all calculated from the separate age classes. The percentage cover of agricultural fields and water bodies, the amount of settlement (number of people), and the total length of roads were derived from digital maps (sources: National Land Survey of Finland, Finnish Road Administration, and Finland's environmental administration). The amount of scattered settlement was calculated as the number of people living outside of population centers according to the community planning follow-up system of Finland's environmental administration in 1990.

Statistical analyses

First, we characterized the relationship between the abundance of capercaillie and moose by calculating correlation coefficients separately for 130 grid cells throughout Finland. One grid cell had to be excluded from the calculations because of the lack of data. The correlations were calculated using the species-specific average abundances in wildlife triangles over the years 1989-2007 in order to emphasize the role of spatial variation and minimize the roles of random variation and temporal trends in our analyses. We used Spearman's rank correlation because the assumption of normality may not hold. The pattern of correlations does not consist of independent values because of the spatial autocorrelation between grid cells. However, we present this correlative surface map as indicative evidence of the spatial contexts defining the relationships between the two species (Fig. 3).

Secondly, in order to examine the differences in requirements between capercaillie and moose, we continued our analyses with a set of linear regression models using the compositional aspects of land use and the structural aspects of forestry as explanatory variables. This approach was based on elaboration, a technique that is widely used to analyze multivariate data in social sciences (Babbie 1987). Elaboration has been applied in ecology by Penttilä et al. (2006), Pellikka et al. (2007) and recently by Kukkonen et al. (2008). The main idea of these analyses was to explore in which contexts and how strongly the assumed difference between species abundances was supported by the data, i.e., which aspects suppress or mask and which seem to promote the contrast (if any). Following this idea, we analyzed how the association between the abundance of capercaillie and moose, represented by a regression slope, changed when variables were included alone or as combinations in the regression model. The former enabled us to generally examine the effects of independent and dependent variables, whereas the latter reduced the role of indirect effects associated with the other included independent variables.

In the analyses, the dependent variable was capercaillie abundance averaged over the years 1989-1996 to temporally correspond as closely as possible with our land use data. Moose abundance was included as the first explanatory variable in the model, and it was retained in the model throughout the modeling procedure (see Table 2). We also performed the same modeling, with moose abundance as the dependent variable, but the interpretation of the results remained the same. Where the absolute value of the regression slope (describing the relationship between capercaillie and moose abundance) drastically decreases to near zero follow- 


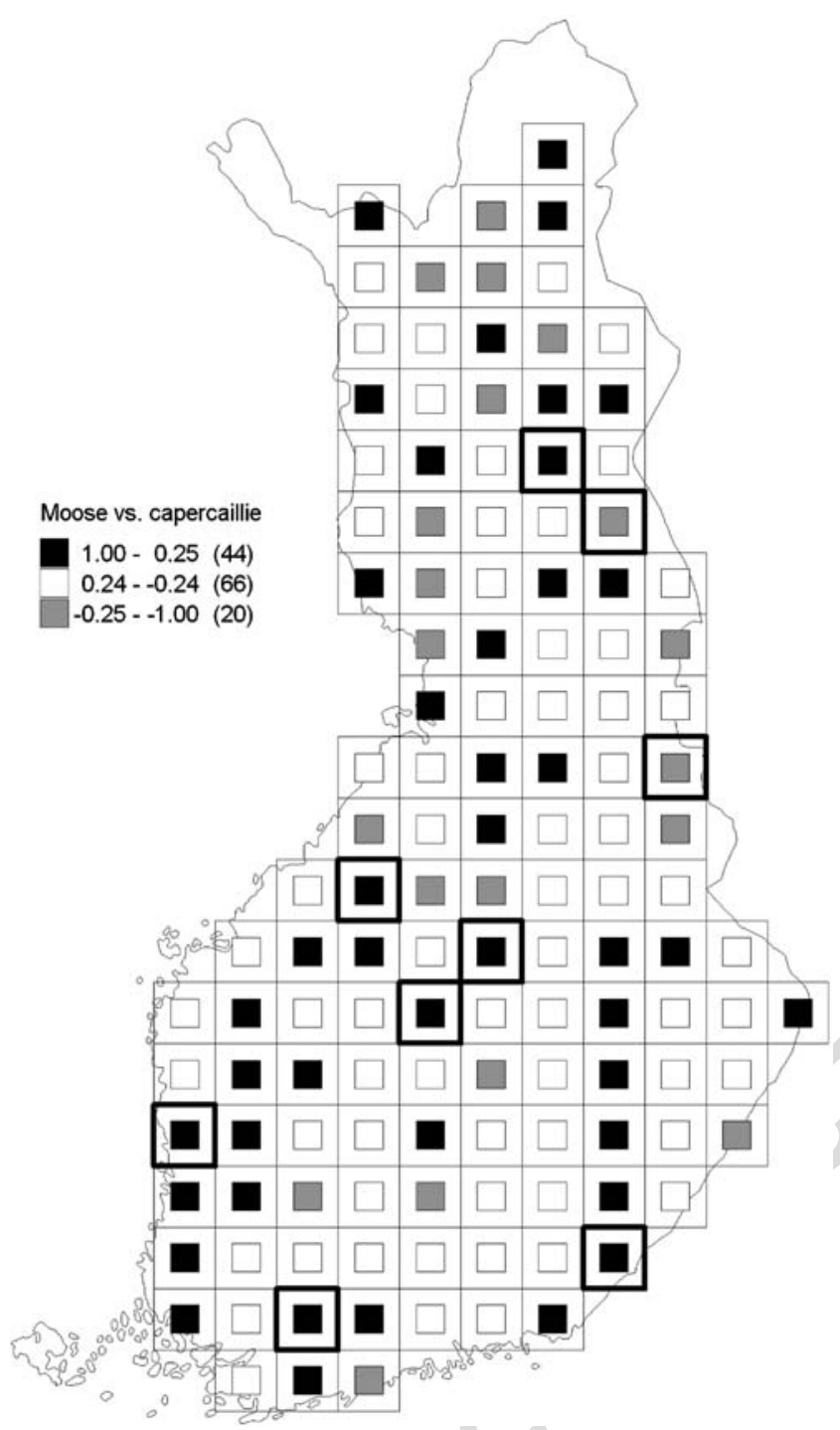

Fig. 3 A correlative surface map illustrating the relationship between the abundances of capercaillie and moose, averaged over the years 1989-2007. The values are Spearman's rank correlation coefficients calculated for every $50-\times 50-\mathrm{km}$ grid cell. Significant $(P \leq 0.05)$ correlations are marked with a bold rim
Table 2 The modeling steps for the dependent variable "capercaillie abundance"

\begin{tabular}{llr}
\hline Step & Model & Condition \\
\hline 1 & MOOSE & \\
2 & MOOSE + AR stepwise selection & $\begin{array}{r}\text { MOOSE forced } \\
\text { into the model } \\
3\end{array}$ \\
4 & $\begin{array}{l}\text { MOOSE }+ \text { AR }+ \text { HI stepwise selection } \\
\text { into the model }\end{array}$ & $\begin{array}{r}\text { MOOSE forced } \\
\text { into the model }\end{array}$ \\
\hline
\end{tabular}

The criterion for inclusion and exclusion of variables by stepwise selection was always $P=0.05$

MOOSE moose abundance, $A R$ age-related variables (i.e., average age of the forest, proportion of forest under 40 years old, proportion of forest over 60 years old), $H I$ human impact variables (i.e., the scattered and total settlement in 1990), TPF total proportion of forest land, UFA unproductive forest area

(Cederlund and Okarma 1988). Thus, we first included the factor AR (age-related variables) into the model, i.e., we performed a stepwise selection among the following variables: (1a) the average age of the forest (AVE), (1b) the proportion of forest under 40 years old $(<40)$, and (1c) the proportion of forest over 60 years old $(>60)$. In Norway, capercaillie habitat was classified as old forest when forests were aged 50 years and older (Gjerde and Wegge 1989). Lekking grounds were mainly found in forest patches older than 60-70 years (e.g., Rolstad and Wegge 1987a).

Secondly, we included the factor HI (human impact variables) in the model, i.e., the following variables were included in the stepwise selection: (2a) the number of people in scattered settlements in 1990 (SCA) and (2b) the total number of people in settlements in 1990 (SET). Here, we did not want to make any presuppositions about the order of factors AR and HI. Therefore, we tested whether our statistical reasoning was sensitive to the order of inclusion of $\mathrm{AR}$ and $\mathrm{HI}$ variables. We found that the variables were redundant with respect to the order of inclusion.

Finally, we included (3a) the TPF and (3b) unproductive forest area in the model using stepwise selection. This was because not only forested areas but also the unproductive forest may play an important role in determining the species abundances. A priori, these two variables should be considered as the least powerful ones explaining the proposed differences in the species responses because both capercaillie and moose are forest animals and probably benefit from high fertility, especially in the northern parts of the country (Pellikka et al. 2006). Thus, we included both the age-related forest variables and the human impact factor and examined whether the remaining variation could be explained by the more general forest landscape and soil fertility effects. The criterion of inclusion and exclusion of variables was always kept at $p=0.05$. 
We conducted the analyses for five separate regions (Fig. 2; see also Pellikka et al. 2006), i.e., South-Western $(n=23)$, South-Eastern $(n=14)$, Western $(n=19)$, Eastern $(n=24)$, and Northern Finland $(n=49)$, in order to take regional characteristics in the landscape into account. We excluded two zero moose abundance cells in Northern Finland from the statistical analyses. In all cases, the residuals of the models were normally distributed. Statistical analysis was performed with SPSS 15 and SAS 8.2 statistical packages.

\section{Results}

\section{Correlation between abundances}

When capercaillie and moose abundances were correlated, only 20 cells out of 130 had a Spearman correlation coefficient below -0.25 . The grid cells with a negative correlation showed no clear spatial pattern, as these cells were relatively evenly distributed throughout Finland. Only two cells close to the eastern border had significant $(P \leq$ $0.05)$ negative correlations between the abundances. In most of Finland ( $62 \%$ of the grid cells), the correlation coefficient was positive. Thus, there was a general tendency that both species reached their highest abundance in the same grid cells. Particularly in southern Finland, the cells with a strong positive correlation formed spatial clusters, indicating a phenomenon that is probably explained by factors operating on scales larger than our smallest unit of analysis (i.e., $50 \times 50 \mathrm{~km}$; Fig. 3).

In the regionally separated regression analyses, the slope describing the relationship between capercaillie and moose had a positive association in Northern as well as SouthEastern Finland (Appendix 1). In other regions, no clear pattern between the species abundances was observed.

\section{Effect of age-related variables}

In Western Finland, the average age of the forest had a positive impact on capercaillie abundance (significant at the level $P \leq 0.05$ assuming grid units to be independent samples). The effect was consistent during the whole modeling procedure, i.e., it was found when testing the variable independently $(B=0.123, t=3.19, P=0.005)$ and during modeling steps 2-4 (see Appendix 1). The inclusion of age-related variables pushed the effect size between capercaillie and moose to virtually zero (Fig. 4).

In Eastern and South-Western Finland, the proportion of forest under 40 years old was included in the model at step 2 with a positive association with capercaillie abundance. In Eastern Finland, the proportion of forest over 60 years old was also positively related to capercaillie abundance at step 2. However, in these regions, all the age-related

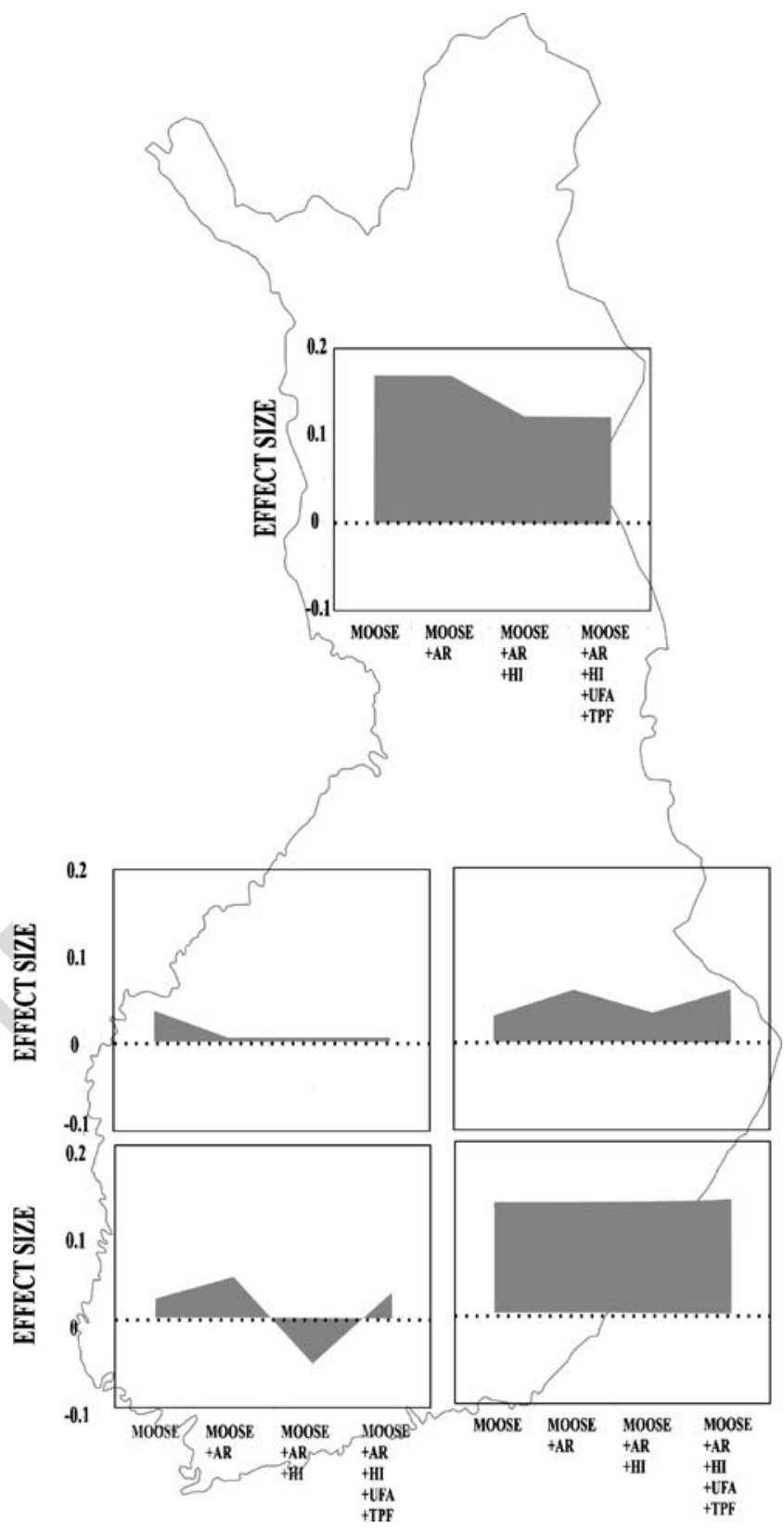

Fig. 4 The relationship between moose and capercaillie abundance at different modeling steps (see Tables 1 and 2 for total variable list and variable codes and Table 2 for modeling steps). The effect size is the coefficient of regression of moose abundance on capercaillie abundance (significant with $P \leq 0.05$ in Northern and South-Eastern Finland; for detailed numerical values, see Appendix 1). A decrease in the absolute value of the regression slope to near zero in conjunction with the inclusion of a variable indicates that, regardless of the change in $P$ values, the variable in question is connected with the difference in species abundances. Conversely, an increase in the absolute value of the slope may reveal variables possibly masking the contrast. Models are regional linear regressions with stepwise selection of independent variables. The criterion of inclusion and exclusion of variables was always $P=0.05$ 
Eur J Wildl Res

360 variables were dropped from the models in further 361 modeling steps. The interaction with the TPF appeared to 362 be the main reason for these effects, and they were masked 363 by the explanatory power of this variable. There was a 364 significant positive correlation between the TPF and forest 365 under 40 years old in both Eastern (Pearson $r=0.684, P<$ $3660.0001)$ and South-Western Finland $(r=0.832, P<0.0001)$ 367 and between the TPF and forest over 60 years (E Fin, $r=$ $3680.667, P=0.0001$; SW Fin, $r=0.839, P<0.0001)$. In both 369 Eastern and South-Western Finland, with the inclusion of 370 age-related variables, the effect size between capercaillie 371 and moose abundances increased (Fig. 4).

Age-related variables also had strong correlations with other model variables in Northern Finland, where there was a strong negative correlation between the average age of the forest and the proportion of scattered settlement (Pearson $r=-0.621$, $P<0.0001)$. Although none of the age-related variables were included in the models in Northern Finland, the average age of the forest had a negative impact on capercaillie abundance when tested independently $(B=-0.018, t=-2.45, P=0.018)$.

\section{Effect of human impact variables}

The human impact (HI) variables were selected from a group of correlative variables that included the proportion of fields and the total length of roads [Pearson $r$ varied between 0.425 and 0.920 , and the $P$ values between 0.0001 and 0.130 in all cases except the comparison of total settlement (SET) versus fields]. There was a positive association between scattered settlement and capercaillie abundance in Northern Finland (see Appendix 1). The amount of scattered settlement had more explanatory power than correlated age-related variables, namely, the average age of the forest (see above). With the inclusion of human impact variables in the regression model, the effect size of moose abundance was reduced but remained significantly positive (Fig. 4).

The effect of scattered settlement turned negative in Eastern and South-Western Finland when the variable was tested independently (E Fin, $B=-0.000, t=-2.28$, $P=0.033$; SW Fin, $B=-0.000, t=-2.10, P=0.048)$. However, during the modeling steps, the variable was not included in the models, but it was masked by the amount of total (scattered and non-scattered) settlement. The amount of total settlement had a negative effect on capercaillie abundance in Eastern and South-Western Finland at step 3 (see Appendix 1). In both Eastern and South-Western Finland, the relationship between moose and capercaillie abundance was reduced with the inclusion of total settlement in the regression model (Fig. 4). In Eastern Finland, the effect size decreased close to that at step 1 but remained positive. In contrast, in South-Western Finland the effect size turned negative.
Effects of forest and unproductive forest cover

The TPF had a positive effect on capercaillie abundance in Eastern and South-Western Finland (Appendix 1). In both regions, the effect size of moose abundance increased when including the TPF in the model. In South-Western Finland, the effect size again turned positive (Fig. 4).

The effect of unproductive forest area was frequently masked by other variables, namely, the TPF and age-related variables. There were strong correlations among all these variables, for example, among the unproductive forest area and the average age of the forest (Pearson $r$ varied between 0.381 and 0.714 , and $P$ values varied between 0.001 and 0.0646 in all other areas except South-Eastern Finland). Hence, for most regions, the variable was not included in the models at all. When tested independently, the unproductive forest area had a positive impact on capercaillie abundance in Eastern Finland $(B=3.697, t=2.35, P=0.028)$ and a negative trend in South-Eastern Finland $(B=-14.051, t=-1.87, P=$ 0.086). However, in South-Eastern Finland, the variable was negatively associated with capercaillie abundance at step 4, after controlling for the effects of other variable groups. When including the unproductive forest area in the model, the effect size of moose abundance slightly increased in South-Eastern Finland (see Appendix 1), suggesting that the negative relationship between unproductive forest area and species abundance is similar for capercaillie and moose.

To summarize, the relationship between capercaillie and moose abundance, i.e., the effect size in Fig. 4, remained mainly positive, irrespective of the region or model step. The downward swing in the effect size curve (Fig. 4), i.e., support for the trade-off hypothesis, was in three out of five regions connected with the effect of human impact variables and in one case connected with forest age.

\section{Discussion}

The relationship between the abundances of capercaillie and moose was not significantly negative in any of the five regions. This provides indicative evidence against the trade-off hypothesis. Unexpectedly, in two of the regions, a significant positive relationship was detected, indicating that the requirements or conditions that determine the large-scale abundance of these two species are shared more than they are divergent.

Effect of age-related variables

In Western Finland, the trade-off hypothesis was partially supported in the sense that capercaillie abundance seems to be more positively associated with older forest than moose abundance. Traditionally, the capercaillie has been thought to be dependent on older forest stages (e.g., Rolstad and Wegge 1987a; Helle et al. 1989). Some more recent studies 
459 similarly indicate that capercaillie seem to prefer older forest 460 whenever it is sufficiently available in the landscape (Helle et 461 al. 1994; Sjöberg 1996; Angelstam 2004). On the contrary, 462 younger forest age classes and plantations are considered as 463 a continuous food supply for moose (Cederlund and 464 Markgren 1987), and clear cuts and young pine stands are 465 often particularly highly used (Cederlund and Okarma 1988).

466 The average age of the forest was negatively associated 467 with capercaillie abundance in Northern Finland. This result is 468 consistent with other recent studies, suggesting that young and 469 middle-aged forest classes are common in the vicinity of high 470 capercaillie abundances in Northern Finland (Miettinen et al. 471 2005). The capercaillie is also capable of forming new 472 lekking sites in young forests (26-46 years old, Rolstad et al. 473 2007; Valkeajärvi et al. 2007). This is somewhat surprising 474 when considering the traditional viewpoint that lists the 475 capercaillie as an "old forest specialist" (e.g., Rolstad and 476 Wegge 1987a). One explanation can be found in the 477 extensive forest management practices (e.g., clear cuttings 478 and forest regeneration by plantations) introduced after 479 World War II and started in Northern Finland (Lindén et al. 480 2000). The total area of clear-cuts and plantations of different 481 ages has grown enormously, nowadays comprising most of 482 the forested area. Hence, forest age might no longer act as a 483 factor distinguishing different quality capercaillie landscapes 484 in Finland, especially in the north (see also Miettinen et al. 485 2008). However, it is important to note that Northern Finland 486 is the largest region of all those considered here and thus 487 contains the greatest variability. The large spatial scale in our 488 study may mask some connections between capercaillie 489 abundance and smaller scale habitat selection.

\section{Effect of human impact variables}

The main reason for the positive association between scattered settlement and the abundance of both species in Northern Finland might be connected to overall soil fertility: Human settlements are generally situated on more fertile grounds (see also Pautasso 2007). Studies conducted in northern Alberta and Alaska (Schneider and Wasel 2000; Maier et al. 2005) reported higher moose densities close to towns due to high-quality food in the surroundings of towns, habituation to people as well as avoidance of predators (i.e., wolves and bears, which do not tolerate humans; see also Stephens and Peterson 1984). In Northern Finland, moose predation by large carnivores is largely hindered by man. Wolves, in particular, are usually shot whenever dispersing into the reindeer husbandry regions in North Finland (Kojola et al. 2006), and the same practice has been reported in Sweden and Norway (Wabakken et al. 2001). For capercaillie, predator avoidance is probably not the cause of the positive human impact because small and middle-sized carnivores usually reach higher densities close to fields and scattered settlements (Kurki et al. 1997). Some of the settlements in the north have followed the locations of good hunting grounds, which may also explain the positive relationship between scattered settlement and capercaillie abundance.

The human impact on both of the species turned negative in Southern Finland (Lindén et al. 2000; Lindén 2002a; Miettinen et al. 2008), showing how important it is to account for geographical gradients in the analyses (Fortin et al. 2008). In South-Western ,Finland the trade-off hypothesis was supported when first controlling for forest age and then including the effect of total settlement in the model (the negative effect size in Fig. 4). It therefore seems that the capercaillie is, to some extent, more affected by the negative aspects of human settlement than the moose. It has been suggested that winter home ranges of moose may have a more distant location from man-made landscapes compared to summer ranges (Nikula et al. 2004). Although roads and moose fences make the approach toward cities difficult for ungulates in Scandinavia (Nellemann et al. 2001), fences may also increase moose densities near roads (Ball and Dahlgren 2002). The capercaillie, on the other hand, is among the grouse species that clearly avoid areas with a heavy human impact (e.g., Helle et al. 1994; Kurki et al. 2000; Storch 2000b, 2007).

\section{Effect of forest cover}

The TPF had a positive impact on capercaillie abundance in Eastern and South-Western Finland. In South-Western Finland, in particular, intensive agriculture and other human land use negatively affects capercaillie. It has been reported, for example, that in Southern Finland, the amount of forest is an important variable in predicting the occurrence of capercaillie lekking sites compared to the average landscape (Lindén and Pasanen 1987; Helle et al. 1994). The positive effect of total forest land is important for the lekking sites up to $1.5 \mathrm{~km}$ distance from the lekking center (Lindén and Pasanen 1987; Helle et al. 1994). Because the minimum size for a lekking area is 300 ha (Wegge and Larsen 1987), capercaillie males seem to have difficulties in forming lekking sites in Southern Finland, probably due to forest loss and fragmentation. In this study, the need for vast forested areas for capercaillie in SouthWestern Finland was clear, even after controlling for forest age and human impact. Several other studies have also reported negative effects of forest loss on capercaillie on different scales (e.g., Rolstad and Wegge 1987b; Kurki et al. 2000; Storch 2000b; Mikusiñski and Angelstam 2004).

Overall forest cover was positively related to the abundance of both capercaillie and moose, as expected. Indeed, on the European scale, the moose is also negatively affected by forest loss (Mikusiñski and Angelstam 2004). Some studies have suggested that not only forest cover but also soil fertility plays an important role in determining moose 
Eur J Wildl Res

abundance. In winter, moose habitat and home ranges include significantly more pine-dominated forest on peatland or shrub land (Heikkilä and Härkönen 1993; Nikula et al. 2004; Cassing et al. 2006). In Finland, the moose is generally more controlled by hunting than the capercaillie. The management of moose aims at a population level that is widely accepted by agriculture, forestry, and road traffic (Haagenrud et al. 1987; Nygrén and Pesonen 1993). In this sense, moose abundance in Finland is first and foremost regulated by humans (Lehtonen 1998). However, to have an effect on our results, the capacity of hunting to regulate abundances should be correlated with our land use variables. In other words, hunting should be more efficient in grid cells with a large proportion of certain land use class(es). According to our knowledge, no clear evidence of such a correlation exists (other than the fact that more animals are hunted in areas with higher population levels). In addition, the use of longterm average abundance values reduces the potential hunting effects in our models. Furthermore, the abundance estimates for moose were collected in winter, while the hunting season is in autumn. Thus, even if moose abundance is lowered to an acceptable level by hunting each autumn, the remaining wintering population may be assumed to seek out and settle in areas with desirable land use characteristics. Nonetheless, it would be of interest to include the effect of hunting in future studies. Regarding the capercaillie, not even the relatively high shooting yields seem to be correlated with grouse population trends in Finland (Lindén 1991).

\section{Conclusion}

To address regional problems in game management, it is important to study large-scale landscape characteristics (for example see Angelstam et al. 2004; Mikusiñski and Angelstam 2004). Landscape patterns on large spatial scales may be informative in predicting phenomena on smaller scales (Gaston 2004; Cassing et al. 2006). However, we cannot simply assume that the patterns and processes at the landscape level or on broader scales are only reflections of habitat-level phenomena (see also Whittingham et al. 2007). Therefore, it is especially important to incorporate several spatial and temporal scales when examining the relationship between species and their environment (Wiens 1989; Levin 1992). Overall, regional game management should be based on data covering both large areas and multiple species requirements.

We observed a general trend that rejects the trade-off hypothesis: The capercaillie and moose do not appear to have dissimilar responses to large-scale land use, despite their divergent habitat requirements. We can reject the hypothesis based on the twofold evidence. First, the correlation between the abundance of capercaillie and moose was mainly positive, indicating that the species are abundant in the same broad areas. Second, further support was given by the regression models, which provided no clear evidence of any examined factor revealing a difference between the species on large spatial scales. Instead, the species responses to landscape variables were in general very similar.

We acknowledge that our explanatory variables, and the scales that we chose, were somewhat coarse. For moose, for example, earlier studies have found evidence of responses on multiple scales, including scales below the level of the habitat patch (Bowyer and Kie 2006). However, we did not intend to create another habitat suitability or habitat use model for these species because this has already been done in several papers (e.g., Allen et al. 1988; Gjerde and Wegge 1989; Dussault et al. 2006; Graf et al. 2005). Many of the studies concerning moose habitat choice have operated either within home ranges or on the landscape level (e.g., Nikula et al. 2004; Dussault et al. 2005; Cassing et al. 2006), and broad landscape-level variables are usually strong predictors of capercaillie occurrence (e.g., Mikusiñski and Angelstam 2004; Graf et al. 2007; Miettinen et al. 2008). Our selection of large spatial scales also appeared appropriate in the light of the results obtained in the sense that the grid cells with a strong positive correlation formed spatial clusters (Fig. 3). In addition, the extent of the study scale $\left(2,500 \mathrm{~km}^{2}\right.$ per grid cell) and our use of long-term average abundance values gives reason to believe that the seasonal differences in species abundances (capercaillie data collected in summer and moose data in winter) are not an important source of error in our analyses. Nonetheless, we stress that our study provides only a preliminary and general overview of the responses of these species to large-scale land use.

It is clear that the existing differences between the species are due to mechanisms mostly operating on finer scales than the ones studied here. On a more local scale, such as the home range and/or a forest stand, the species probably occupy different habitats. This may be one reason for the observed contrasting population trends of capercaillie and moose (Fig. 1). However, it seems to be too strong to argue that capercaillie and moose have completely opposite environmental requirements. While considering regional land use planning, the primary goal for both species seems to be to secure large enough areas of forest, preferably at a distance from human settlement (e.g., Storch 2000b; Mikusiñski and Angelstam 2004).

Acknowledgments We thank Pekka Helle, Hanna Kokko, Ari Nikula, and Hannu Rita for their valuable comments on the manuscript. We are grateful to Marcus Wikman for help in the preparation of Fig. 1. We also express our gratitude to the hunters and other volunteers in Finland who have been collecting the wildlife triangle data.

Integrity of research and reporting All research presented complies with the current laws of the country. The authors declare that they have no conflicts of interest. 


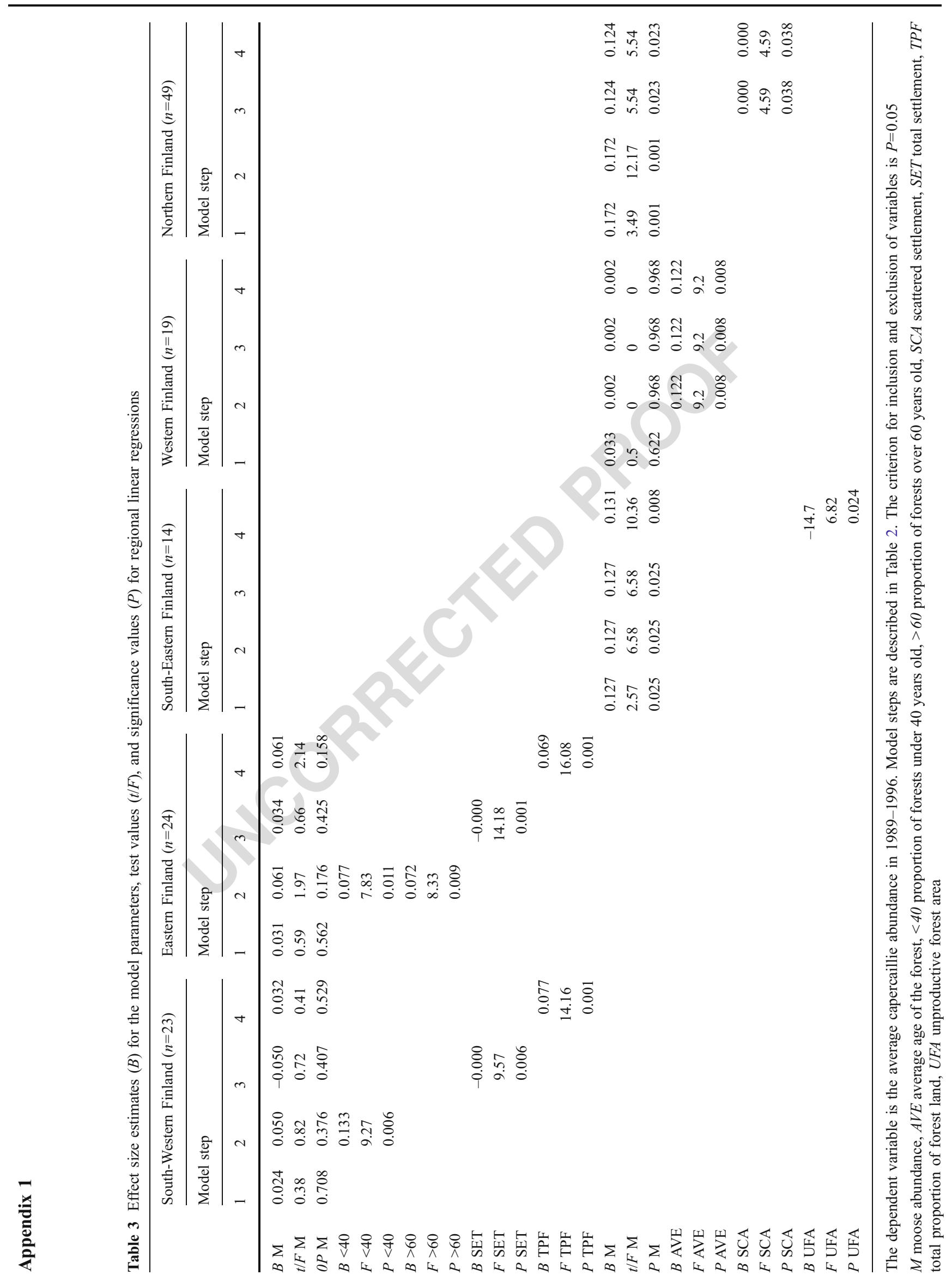

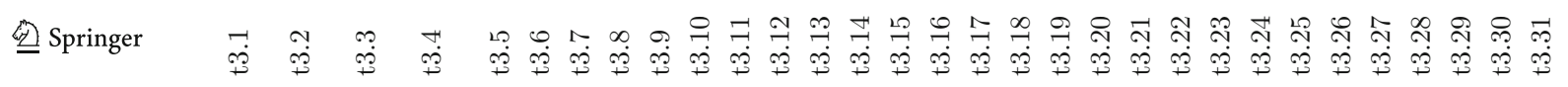


Eur J Wildl Res

\section{$716 \quad$ References} 225
Allen AW, Terrell JW, Jordan PA (1988) An overview of a habitat suitability index model for moose: Lake Superior region. Alces 24:118-125

Andrewartha HG, Birch LC (1954) The distribution and abundance of animals. University of Chicago Press, Chicago

Angelstam P (2004) Habitat thresholds and effects of forest landscape change on the distribution and abundance of black grouse and capercaillie. Ecol Bull 51:173-187

Angelstam P, Edman T, Dönz-Breuss M, Wallis DeVries MF (2004) Land management data and terrestrial vertebrates as indicators of forest biodiversity at the landscape scale. Ecol Bull 51:333-349

Babbie ER (1987) The practice of social research, 5th edn. Wadsworth, Belmont

Baines D, Summers RW (1997) Assessment of bird collisions with deer fences in Scottish forests. J Appl Ecol 34:941-948

Ball JP, Dahlgren J (2002) Browsing damage on pine (Pinus sylvestris and $P$. concorta) by a migrating moose (Alces alces) population in winter: relation to habitat composition and road barriers. Scand J For Res 17:427-435

Bevanger K (1995) Estimates and population consequences of tetraonid mortality caused by collisions with high tension power lines in Norway. J Appl Ecol 32:745-753

Bowyer TR, Kie JG (2006) Effects of scale on interpreting life-history characteristics of ungulates and carnivores. Divers Distrib $12: 244-257$

Cassing G, Greenberg LA, Mikusiñski G (2006) Moose (Alces alces) browsing in young forest stands in central Sweden: a multiscale perspective. Scand J For Res 21:221-230

Cederlund G, Markgren G (1987) The development of the Swedish moose population, 1970-1983. Swed Wildlife Res Viltrevy Suppl 1(Part 1):55-62

Cederlund G, Okarma H (1988) Home range and habitat use of adult female moose. J Wildl Manage 52:336-343

Child KN, Stuart KM (1987) Vehicle and train collision fatalities of moose: some management and socio-economic considerations. Swed Wildlife Res Viltrevy Suppl 1(Part 2):699-703

Dussault C, Ouellet J-P, Courtois R, Huot J, Breton L, Jolicoeur H (2005) Linking moose habitat selection to limiting factors. Ecography 28:619-628

Dussault C, Courtois R, Ouellet J-P (2006) A habitat suitability index to assess moose habitat selection at multiple spatial scales. Can J For Res 36:1097-1107

Forman RTT, Godron M (1986) Landscape ecology. Wiley, New York Fortin D, Courtois R, Etcheverry P, Dussault C, Gingras A (2008) Winter selection of landscapes by woodland caribou: behavioural response to geographic gradients in habitat attributes. J Appl Ecol 45:1392-1400

Gaston KJ (2004) Macroecology and people. Basic Appl Ecol 5:303-307

Gjerde I, Wegge P (1989) Spacing pattern, habitat use and survival of Capercaillie in a fragmented winter habitat. Ornis Scand 20:219-

Graf RF, Bollmann K, Suter W, Bugmann H (2005) The importance of spatial scale in habitat models: capercaillie in the Swiss Alps. Landscape Ecol 20:703-717

Graf RF, Bollmann K, Bugmann H, Suter W (2007) Forest and landscape structure as predictors of capercaillie occurrence. J Wildl Manage 71:356-365

Haagenrud H, Morow K, Nygrén K, Stålfelt F (1987) Management of moose in Nordic countries. Swed Wildlife Res Suppl 1(Part 2):635642 Viltrevy

Heikkilä R, Härkönen S (1993) Moose (Alces alces L.) browsing in young Scots pine stands in relation to the characteristics of their winter habitats. Silva Fenn 27:127-143
Heikkinen S (2000) The year of the moose. Suomen Riista 46:82-91 (In Finnish with English summary)

Helle T, Helle P, Lindén H, Kilpelä S-S (1989) Stand characteristics of capercaillie lekking sites in northern Finland. Suomen Riista 35:26-35 (In Finnish with English summary)

Helle P, Helle T, Lindén H (1994) Capercaillie (Tetrao urogallus) lekking sites in fragmented Finnish forest landscape. Scand $\mathrm{J}$ for Res 9:386-396

Johnson DH (1980) The comparison of usage and availability measurements for evaluating resource preference. Ecology 61:65-71

Kie JG, Bowyer RT, Nicholson MC, Boroski BB, Loft ER (2002) Landscape heterogeneity at differing scales: effects on spatial distribution of mule deer. Ecology 83:530-544

Kojola I, Aspi J, Hakala A, Heikkinen S, Ronkainen S (2006) Dispersal in an expanding wolf population in Finland. J Mammal 87:281-286

Kukkonen M, Rita H, Hohnwald S, Nygren A (2008) Treefall gaps of certified, conventionally managed and natural forests as regeneration sites for Neotropical timber trees in northern Honduras. For Ecol Manag. doi:10.1016/j.foreco.2007.12.030

Kurki S, Helle P, Lindén H, Nikula A (1997) Breeding success of black grouse and capercaillie in relation to mammalian predator densities on two spatial scales. Oikos 79:301-310

Kurki S, Nikula A, Helle P, Lindén H (2000) Landscape fragmentation and forest composition effects on grouse breeding success in boreal forests. Ecology 81:1985-1997

Lavsund S (1987) Moose relationships to forestry in Finland, Norway and Sweden. Swed Wildl Res Viltrevy Suppl 1(Part 1):229-244

Lehtonen A (1998) Managing moose, Alces alces, population in Finland: hunting virtual animals. Ann Zool Fennici 35:173-179

Leinonen K, Ermala A (1995) Metsästäjäprofiili 1993, Osaraportti 2, Kala- ja riistaraportteja 33. Tilastotoimi, Helsinki (In Finnish)

Levin SA (1992) The problem of pattern and scale in ecology. Ecology 73:1943-1967

Lindén H (1991) Patterns of grouse shooting in Finland. Ornis Scand 22:241-244

Lindén H (2002a) The capercaillie - a focal species in landscape ecology at three different scales. Suomen Riista 48:34-45 (In Finnish with English summary)

Lindén H (ed) (2002b) Metsäkanalintututkimuksia: Metsäkanalintukannat. Gummerus Kirjapaino Oy, Saarijärvi (In Finnish)

Lindén H, Pasanen J (1987) Capercaillie leks are threatened by forest fragmentation. Suomen Riista 34:66-76 (In Finnish with English summary)

Lindén H, Helle E, Helle P, Wikman M (1996) Wildlife triangle scheme in Finland: methods and aims for monitoring wildlife populations. Finn Game Res 49:4-11

Lindén H, Danilov PI, Gromtsev AN, Helle P, Ivanter EV, Kurhinen J (2000) Large-scale forest corridors to connect the taiga fauna to Fennoscandia. Wildlife Biol 6:179-188

Ludwig GX, Alatalo RV, Helle P, Nissinen K, Siitari H (2008) Largescale drainage and breeding success in boreal forest grouse. $\mathrm{J}$ Appl Ecol 45:325-333. doi:10.1111/j.1365-2664.2007.01396.x

Maier JAK, Ver Hoef JM, McGuire AD, Bowyer RT, Saperstein L, Maier HA (2005) Distribution and density of moose in relation to landscape characteristics: effects of scale. Can J For Res 35:2233-2243

Miettinen J, Helle P, Nikula A (2005) Lek area characteristics of capercaillie (Tetrao urogallus) in eastern Finland as analysed from satellite-based forest inventory data. Scand J For Res 20:358-369

Miettinen J, Helle P, Nikula A, Niemelä P (2008) Large-scale landscape composition and capercaillie (Tetrao urogallus) density in Finland. Ann Zool Fenn 45:161-173

Mikusiñski G, Angelstam P (2004) Occurrence of mammals and birds with different ecological characteristics in relation to forest cover
780 
in Europe - do macroecological data make sense? Ecol Bull 51:265-275

Nellemann C, Vistnes I, Jordhøy P, Strand O (2001) Winter distribution of wild reindeer in relation to power lines, roads and resorts. Biol Conserv 101:351-360

Nikula A, Heikkinen S, Helle E (2004) Habitat selection of adult moose Alces alces at two spatial scales in central Finland. Wildlife Biol 10:121-135

Nygrén T (1987) The history of moose in Finland. Swed Wildl Res Viltrevy Suppl 1(Part 1):49-54

Nygrén T (1996) Hirvi. In: Lindén H, Hario M, Wikman M (eds) Riistan Jäljille. Riista- ja kalatalouden tutkimuslaitos, Edita, Helsinki, pp 103-108 (In Finnish)

Nygrén T, Pesonen M (1993) The moose population (Alces alces L.) and methods of moose management in Finland, 1975-89. Finn Game Res 48:46-53

Pakkala T, Pellikka J, Lindén H (2003) Capercaillie (Tetrao urogallus) _ a good candidate for an umbrella species in taiga forests. Wildlife Biol 9:309-316

Pautasso M (2007) Scale dependence of the correlation between human population presence and vertebrate and plant species richness. Ecol Lett 10:16-24

Pellikka J, Lindén H, Nikula A (2006) Does wildlife richness reflect the large-scale land use patterns? Suomen Riista 52:62-75 (In Finnish with English summary)

Pellikka J, Lindén H, Rita H, Svensberg M (2007) Motives for voluntary wildlife monitoring in Finnish hunting teams. Wildlife Biol 13:1-10

Penttilä R, Lindgren M, Miettinen O, Rita H, Hanski I (2006) Consequences of forest fragmentation for polyporous fungi at two spatial scales. Oikos 114:225-240

Pusenius J, Pesonen M, Tykkyläinen R, Wallén M, Huittinen A (2008) Hirvikannan koko ja vasatuotto vuonna 2006. In: Wikman, M (ed) Riistakannat 2007: riistaseurantojen tulokset. Riista- ja kalatalouden tutkimuslaitos, Helsinki, pp 7-14 (In Finnish)

Rajala P (1974) The structure and reproduction of Finnish populations of capercaillie, Tetrao urogallus, and black grouse, Lyrurus tetrix, on the basis of late summer census data. Finn Game Res 35:1-51

Rolstad J, Wegge P (1987a) Habitat characteristics of Capercaillie Tetrao urogallus display grounds in southeastern Norway. Holarct Ecol 10:219-229

Rolstad J, Wegge P (1987b) Distribution and size of capercaillie leks in relation to old forest fragmentation. Oecologia 72:389-394

Rolstad J, Wegge P (1989) Effects of logging on capercaillie Tetrao urogallus leks. III. Extinction and recolonization on lek populations in relation to clearfelling and fragmentation of old forest. Scand J For Res 4:129-135

Rolstad J, Rolstad E, Wegge P (2007) Capercaillie Tetrao urogallus lek formation in young forest. Wildlife Biol 13(Suppl 1):59-67
Schneider RR, Wasel S (2000) The effect of human settlement on the density of moose in northern Alberta. J Wildl Manage 64:513-520

Seiskari P (1958) Metsiemme kehityksen vaikutuksesta riistalajien elinmahdollisuuksiin. Suomen Riista 12:21-42 (In Finnish)

Sjöberg K (1996) Modern forestry and the capercaillie. In: DeGraaf RM, Miller RI (eds) Conservation of faunal diversity in forested landscapes. Chapman \& Hall, New York, pp 111-135

Smith FA, Lyons SK, Ernest SKM, Brown JH (2008) Macroecology: more than the division of food and space among species on continents. Prog Phys Geogr 32:115-138

Stephens PW, Peterson RO (1984) Wolf-avoidance strategies of moose. Holarct Ecol 7:239-244

Storch I (1993a) Habitat selection by capercaillie in summer and autumn: is bilberry important? Oecologia 95:257-265

Storch I (1993b) Patterns and strategies of winter habitat selection in alpine capercaillie. Ecography 16:351-359

Storch I (2000a) Grouse status survey and conservation action plan 2000-2004. WPA/BirdLife/SSC Grouse Specialist Group, IUCN, Gland

Storch I (2000b) Conservation status and threats to grouse worldwide: an overview. Wildlife Biol 6:195-204

Storch I (2007) Conservation status of grouse worldwide: an update. Wildlife Biol 13(Suppl 1):5-12

Suter W, Graf RF, Hess R (2002) Capercaillie (Tetrao urogallus) and avian biodiversity: testing the umbrella-species concept. Conserv Biol 16:778-788

Taavitsainen J-P (1980) Distribution of the moose in Finland in prehistoric times in the light of archaeological evidence. Suomen Riista 28:5-14 (In Finnish with English summary)

Tomppo E, Katila M, Moilanen J, Mäkelä H, Peräsaari J (1998) Kunnittaiset metsävaratiedot 1990-94. Metsätieteen aikakauskirja 4B/1998:619-839 (In Finnish)

Valkeajärvi P, Ijäs L, Lamberg T (2007) Capercaillie display grounds move - short and long term observations. Suomen Riista 53:104 120 (In Finnish with English summary)

Wabakken P, Sand H, Liberg O, Bjärvall A (2001) The recovery, distribution, and population dynamics of wolves on the Scandinavian peninsula, 1978-1998. Can J Zool 79:710-725

Webb TJ, Noble D, Freckleton RP (2007) Abundance-occupancy dynamics in a human dominated environment: linking interspecific and intraspecific trends in British farmland and woodland birds. J Anim Ecol 76:123-134

Wegge P, Larsen BB (1987) Spacing of adult and subadult male common capercaillie during the breeding season. Auk 104:481-490

Whittingham MJ, Krebs JR, Swetnam RD, Vickery JA, Wilson JD, Freckleton RP (2007) Should conservation strategies consider spatial generality? Farmland birds show regional not national patterns of habitat association. Ecol Lett 10:25-35

Wiens JA (1989) Spatial scaling in ecology. Funct Ecol 3:385-397 